\title{
Tackling a case of a stent lost in calcified right coronary artery: a novel implication of intravascular ultrasound
}

\author{
Naveen Chandra Ganiga Sanjeeva, Padmakumar Ramachandran, Jwalit Morakhia, \\ Rohith Reddy Poondru
}

Department of Cardiology, Kasturba Medical College, Manipal University, Manipal, Karnataka, India

\section{Correspondence to} Dr Naveen Chandra Ganiga Sanjeeva,

drnaveenchandrags@gmail.com

Accepted 14 October 2015

\section{CrossMark}

\section{To cite: Ganiga}

Sanjeeva NC,

Ramachandran $\mathrm{P}$,

Morakhia J, et al. BMJ Case Rep Published online:

[please include Day Month

Year] doi:10.1136/bcr-2015-

212729

\section{DESCRIPTION}

A 55-year-old man with a history of coronary artery bypass graft surgery presented to us with unstable angina. Preliminary investigations showed new ST depressions in inferior leads and elevated cardiac enzymes (Trop T and CKMB). A coronary angiogram was performed showing an occluded venous graft to the right coronary artery (RCA), with a haemodynamically significant heavily calcified lesion in the proximal and mid RCA (figure 1A). Angioplasty and stenting to the native RCA was planned. After adequate predilation of the lesion, the RCA was stented with a $3.5 \times 28 \mathrm{~mm}$ everolimus eluting stent. As there was a residual lesion distal to the stented segment, we planned to stent the distal segment with a $3.5 \times 24 \mathrm{~mm}$ everolimus eluting stent (figure 1B). During stent inflation, a rupture of the stent balloon occurred with partial stent inflation. All attempts to retrieve the stent were unsuccessful; crushing the uninflated stent with another stent was the only option left. As the artery was severely calcified, it was difficult to precisely locate the dislodged stent. An intravascular ultrasound (IVUS) was performed on the RCA through the parallel coronary wire, showing a heavily calcified vessel and the unexpanded stent (figure1C and video 1), which had migrated $5 \mathrm{~mm}$ distal to the proximal stent. With IVUS we could precisely locate the segment of the vessel where the unexpanded stent was; it was covered by a $3.5 \times 38$ everolimus eluting stent with good results (figure 1D).

Stent dislodgement is more common in tortuous and calcified lesions. Although several techniques for the retrieval of stents have been described in the literature, ${ }^{1}$ none have been consistently successful. Crushing the dislodged stent with another coronary stent may be considered when all retrieval techniques fail. Although IVUS has shown to be very useful in optimising results of angioplasty, its role in managing the complications of coronary intervention cannot be ignored. Utility of IVUS in such cases of stent dislodgement has been reported in the literature. ${ }^{2}{ }^{3}$ In our case, localisation of the dislodged stent was very difficult in view of heavy calcification. IVUS helped in localising the
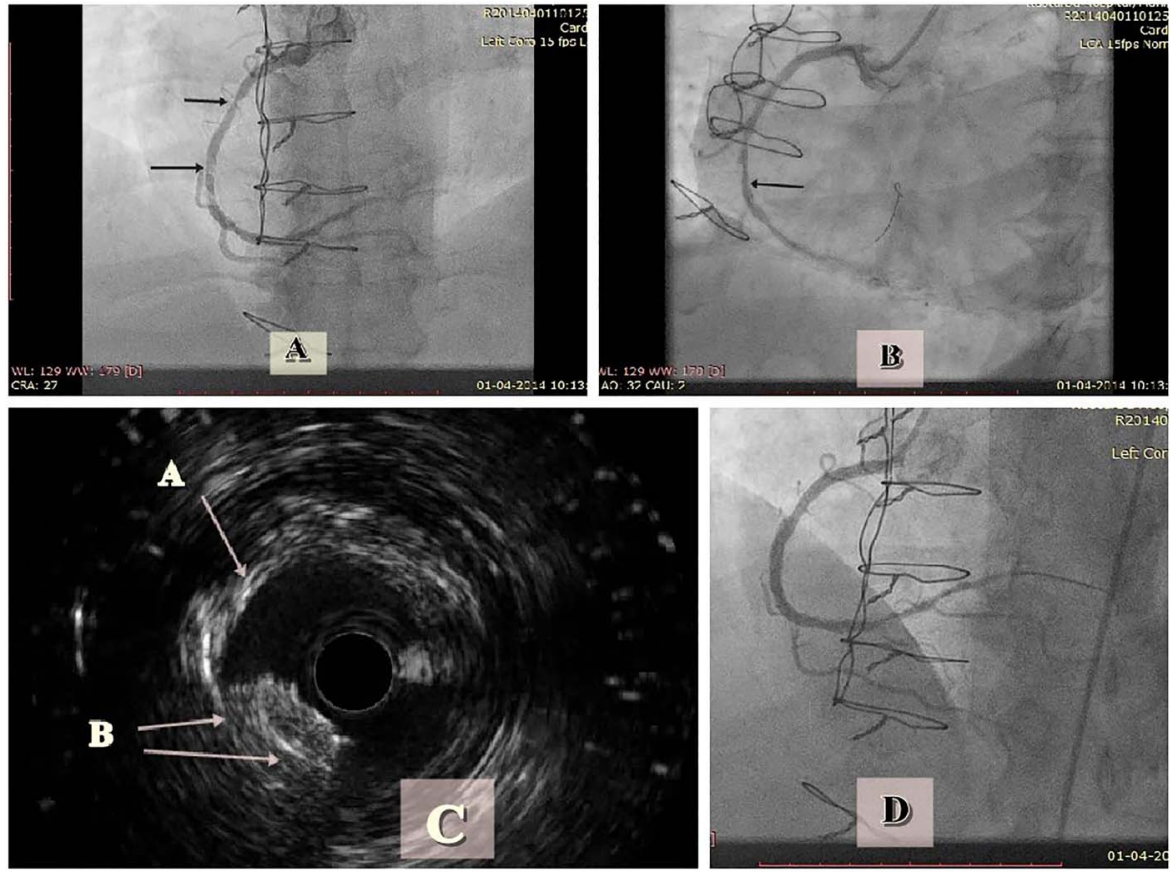

Figure 1 (A) Right coronary artery (RCA) angiogram showing significant calcified lesion in proximal and mid RCA (arrow marks). (B) Post-stenting angiogram showing residual lesion distal to the stented segment being stented with $3.5 \times 24 \mathrm{~mm}$ everolimus eluting stent (arrow marks). (C) Intravascular ultrasound of the RCA showing heavily calcified vessels (a), and dislodged unexpanded stent at $70^{\prime}$ clock position (b). (D) Final result post-stenting. 


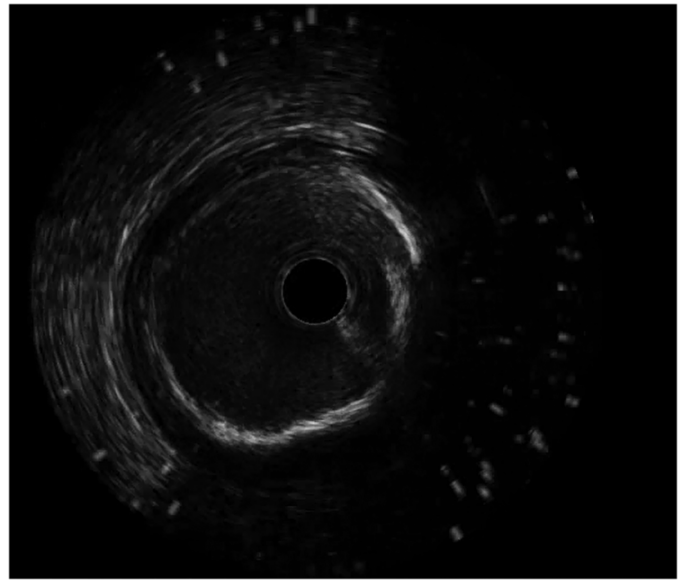

Video 1 Intravascular ultrasound of the right coronary artery showing heavily calcified vessels and dislodged unexpanded stent at $70^{\prime}$ clock position

dislodged stent and delineated the coronary artery segment that had to be stented. Through this report, we want to emphasise that not only does the use of IVUS optimise the results of stenting, it can also be used to manage difficult complications arising during coronary intervention.

\section{Learning points}

- Stent dislodgement and embolisation is an uncommon complication in the era of balloon expanded stents.

- Stent dislodgement is more common in tortuous and calcified lesions.

- Stent retrieval remains the best option in such cases, but may not be possible in all cases.

- Intravascular ultrasound helps in managing some of the most difficult complications during coronary intervention, such as a dislodged stent.

Competing interests None declared.

Patient consent Obtained.

Provenance and peer review Not commissioned; externally peer reviewed.

\section{REFERENCES}

1 Foster-Smith KW, Garratt KN, Higano ST, et al. Retrieval techniques for managing flexible intracoronary stent misplacement. Cathet Cardiovasc Diagn 1993:30:63-8.

2 Goldberg A, Kemer A, Anne G, et al. One stent lost in two arteries. J Invasive Cardiol 2004;16:163-4.

3 Sanchez-Recalde A, Moreno R, Martín Reyes R, et al. Role of intravascular ultrasound in the management of intracoronary dislodged stent. Int J Cardiol 2007;119:e27-9.

Copyright 2015 BMJ Publishing Group. All rights reserved. For permission to reuse any of this content visit http://group.bmj.com/group/rights-licensing/permissions.

BMJ Case Report Fellows may re-use this article for personal use and teaching without any further permission.

Become a Fellow of BMJ Case Reports today and you can:

- Submit as many cases as you like

- Enjoy fast sympathetic peer review and rapid publication of accepted articles

- Access all the published articles

- Re-use any of the published material for personal use and teaching without further permission

For information on Institutional Fellowships contact consortiasales@bmjgroup.com

Visit casereports.bmj.com for more articles like this and to become a Fellow 